\title{
Könyvtár, könyvtárak, könyvtárosok
}

- Halló, tudakozó? Érdeklődnék, mikor nyit a helyi uszoda?

- Hát, az attól függ, honnan hív.

Minden hely uszodája a „helyi uszoda”, ezért nem mindegy, hogy az érdeklődő honnan telefonál. Sok helyen van helyi könyvtár, iskola, kocsma, konditerem is. Amíg a könyvtárba (vagy iskolába, kocsmába, konditerembe) el kell menni könyveket olvasni vagy kölcsönözni (vagy tanulni, alkoholizálni, edzeni), addig lényeges kérdés, hogy hol van az adott épület. De amint belépünk a digitális világba, döntő különbség jelenik meg az uszoda (iskola, kocsma, konditerem), illetve a könyvtár között. Nicholas Negroponte híres metaforája szerint nem mindegy, hogy atomokat (anyagot) vagy biteket (információt) kell-e mozgatnunk. ${ }^{1}$ Az anyag mozgatása mindig a térhez kötött, a digitális átalakulás ebből a szempontból nem hoz lényegi változást. Az információ mozgatása azonban - bizonyos értelemben - függetleníti az embert a helytől (és az időtől). A hálózaton keresztül bárhonnan, bármikor elérhetjük a szükséges információt (tekintsük el most a jogi korlátoktól). Csak az információnak kell mozognia, nekünk nem. Tehát mindegy, hogy hol vagyunk.

Ebben az esetben azonban fel kell tenni azt a kérdést is, hogy mi szükség van, egyáltalán van-e szükség könyvtárakra a digitális átalakulás után. Itt most fontos a többes szám! Egy digitális könyvtárra biztosan szükség lesz a digitális jövőben, hiszen a könyveket, a könyvek metaadatait valahonnan szolgáltatni kell. De arra a kérdésre már nem egyszerü válaszolni, hogy szükségünk lenne-e több könyvtárra, ha minden könyv egyetlen könyvtárból is elérhető.

A predigitális korban valamennyi könyvtár ugyanazt a szolgáltatást nyújtotta az olvasóknak. Amikor megjelent egy kiadvány, akkor annak példányai bekerültek a könyvtárak állományába. A könyvekhez a könyvtárakon keresztül lehetett hozzáférni (amennyiben valaki nem akarta, vagy nem tudta megvásárolni öket). Minden helyi könyvtárban csak azt a könyvet lehetett olvasni, illetve kölcsönözni, amely bekerült az állományába. Ugyanakkor sok száz, sok ezer könyvtár kínálta ugyanannak a könyvnek egyes példányait. Könnyü megválaszolni, hogy ez miért volt így. Amíg az emberek szét vannak szórva a térben, a könyveket csak úgy lehetett eljuttatni hozzájuk, ha azok is „szét vannak terítve”

${ }^{1}$ Negroponte, Nicholas: Digitális létezés. Budapest, Typotex. 2004. 
a térben. Mindaddig, amíg egy könyv tartalmát nem lehetett elérni egy digitális hálózaton keresztül (csak analóg hordozón, például papíron, vagy nem-hálózati digitális hordozón, például floppylemezen vagy CD-ROM-on), addig a könyvtárnak ugyanaz volt a szerepe, mint más intézményeknek (iskolának, kocsmának, konditeremnek): teret biztosított egy adott tevékenység számára. El kellett menni a helyszínre, hogy hozzá lehessen férni a könyvhöz (taneszközhöz, alkoholhoz, sporteszközhöz). A könyvtár jövőjével kapcsolatban azt kell megvizsgálnunk, hogy a digitális korszakváltással mi és miként változik meg a könyv, a könyvtár és a tér viszonyában.

A hagyományos könyvtárhoz kapcsolódóan három térfogalmat (és hozzájuk kapcsolható funkciót) kell elkülönítenünk. A raktár az, ahol a könyveket tárolják, a katalógusterem az, ahol a könyvek megtalálásához szükséges metaadatok között lehet keresni, az olvasóterem pedig az, ahol a látogatók olvassák a könyveket. A hagyományos könyvtárban mindhárom térre és funkcióra szükség van. A könyvek tartalma és metaadatai mindenhol megegyeznek (ebben az értelemben univerzálisak), de a könyvekhez való hozzájutás megkívánja azt, hogy hozzáférhetők legyenek a konkrét példányok: a metaadatok példányai katalógusteremben, a könyvek példányai a raktárban, illetve az olvasóteremben, az olvasók kezében. A predigitális korban nagyon sok raktárra, katalógusteremre és sok olvasóteremre volt szükség a térben szétszórt, lokális érdeklők olvasási igényeinek kielégítéséhez.

A digitális világ radikálisan átalakítja a könyvtárak térhez való viszonyát. Mind a könyvek tartalma, mind a könyveket leíró metaadatok információs jószágok (információs termékek), és rendelkeznek az információs termékek azon sajátosságával, hogy nem-versengö fogyasztásúak - vagyis egy könyv tartalmát befogadhatjuk (fogyaszthatjuk) úgy, hogy ezzel nem akadályozunk meg másokat abban, hogy ők is befogadhassák (fogyaszthassák) ugyanazt a tartalmat. Maga a termék - tehát a csere tárgyát képező információ vagy tartalom - független az anyagi hordozótól. Az információs termékek további fontos vonása, hogy az elöállitásuk erőforrásigénye jóval nagyobb, mint a sokszorosításuké. ${ }^{2}$ Mindezek ismeretében lássuk, hogy mivel jár a könyvtárak digitális átalakulása.

A digitális kommunikáció egyik meghatározó vonása az, hogy a digitális információ másolása nagyon könnyü: bárki bármilyen (típusú és méretü) digitális dokumentumról egyetlen mozdulattal készíthet másolatot. Ebből az következik, hogy a korábban domináns ipari-termelési-sokszorosítási logika lassan átalakul,

${ }^{2}$ Shapiro, Carl - Varian, Hal R.: Az információ uralma: a digitális világ gazdaságtana. Budapest, Geopress. 2000.; Dragomirescu, Horatiu - Vafopoulos, Michalis: Az infonómiától a Webonómiáig: Hogyan alakítja az információs és kommunikációs technológia az információról mint az üzleti tevékenység tárgyáról alkotott képünket? = Információs társadalom, 16. évf. 2016. 2. sz. 61-68. p. 
a sokszorosítás tevékenysége a cégek oldaláról átkerül a fogyasztók oldalára, ${ }^{3}$ és idővel az eddig érvényes szerzői jogi rezsim is fenntarthatatlanná válik, mivel a másolás jogának (copyright) monopóliumát technikai értelemben már nem (vagy csak nagyon nehezen) lehet biztosítani. A kreatív iparágaknak ezért kellett más üzleti modelleket keresniük a digitális környezetben. A zeneipar és a filmipar már a kétezres évek elején szembesült ezzel a kihívással, és alighanem a könyviparra is ez a sors vár. De a könyvipar üzleti modelljének - esetleges - átalakulásánál fontosabb az a változás, ami a könyvek sokszorosítása terén valósul meg. Amennyiben ugyanis a digitális könyveket, pontosabban azok tartalmát elérhetővé tesszük a hálózaton keresztül, akkor elvileg elegendő, ha az érdeklődők egyetlen helyröl, egyetlen kattintással lekérhetik maguknak (azaz másolatot készítenek róla). Így nincs szükség „,központi” sokszorosításra, tehát arra, hogy sok könyvtárba szórjuk szét az egyes könyvek másolatait (példányait). Elméletileg elegendö, ha egyetlen digitális könyvtár biztosítja, hogy a hálózati látogatók hozzáférjenek a keresett könyvekhez (és „elvigyék”, lemásolják maguknak a „saját példányukat”). A jövő könyvtárának nincs szüksége a hagyományos értelemben vett raktárteremre, hiszen a digitális könyveket valamilyen digitális hordozón tárolják az erre szakosodott szerverparkokban az erre szakosodott informatikusok segítségével.

A könyvek tartalma mellett a könyvtári világ másik fontos információtípusa a könyveket leíró metaadat. Ebben az esetben is igaz az a tétel, hogy az ilyen információ előállításának jóval nagyobb az erőforrásigénye, mint a másolásának. A metaadatokhoz való hozzáférés kérdését azonban bonyolítja, hogy a metaadatot önmagában nem tudjuk sem értelmezni (elméletileg), sem kezelni (gyakorlatilag), amíg nem vesszük figyelembe azt az informatikai rendszert, amely a metaadat kezelését (létezését, fenntartását) lehetővé teszi. A digitális világban a könyveket leíró metaadatokat az e célra kialakított, adatbázis alapú könyvtári rendszerek segítségével kezeljük. A felhőszolgáltatások megjelenéséig ezek a könyvtári rendszerek szükségszerüen az egyedi könyvtárakhoz kötött, roszszul integrált egyedi rendszerek voltak, és ez a gyakorlat többféle értelemben is „pazarló” volt. Egyrészt minden egyes könyvtár(i rendszer) esetében biztosítani kellett a müködtetéséhez szükséges informatikai - hardveres és szoftveres - eszközöket, valamint az ezek kezeléséhez szükséges informatikai kompetenciát. Ez drága volt, és abban az értelemben fölösleges, hogy a technikai alapok, valamint az informatikusok mindenhol ugyanannak a munkának az elvégzését szolgálták. Másrészt minden könyvtári rendszerben újra és újra fel kellett venni a könyvek metaadatait, ami megint csak azt jelentette, hogy minden egyes könyvtárban ugyanazt a munkát kellett elvégezniük a könyvtárosoknak. Ez még akkor is így volt, ha a katalógusrekordok gépi adatcseréje lehetőséget nyújtott a máshol már elvégzett munka újrahasznosítására. A könyvek metaadatai közül a formai leíró

\footnotetext{
${ }^{3}$ Syi: Egyben az egész. Budapest, Typotex. 2008.
} 
adatokat minden könyvárnak ugyanúgy kell felvennie, ezért ezekben nem lehet különbség. A tartalmi leíró metaadatok terén azonban lehettek/lehetnek különbségek, hiszen bizonyos könyvtárak esetében volt/van igény (és kompetencia) arra, hogy másként - árnyaltabban, bővebben - írjanak le bizonyos könyveket. Ezek a különbségek azonban kezelhetők megfelelő informatikai támogatással, hiszen ugyanahhoz a könyvhöz többféle tartalmi leírást is hozzá lehet rendelni, így ez sem szolgáltat elég indokot arra, hogy a jövőben a katalogizálást különkülön, nem integráltan, párhuzamos rendszerekben végezzék a könyvtárosok.

A digitális átalakulás fölöslegessé teszi a könyvtárak katalógustermeit is, hiszen elméletileg elegendő egyetlen hely a digitális térben, ahol keresni lehet a metaadatok között. Az új világban egyetlen digitális könyvtár is képes lehet kiszolgálni a valós térben továbbra is szétszórt emberek igényeit. Ha minden könyvet és minden metaadatot digitalizálunk, akkor bárhonnan hozzáférhetünk bármilyen könyvtári információhoz. Ma még messze vagyunk a teljes digitalizálás megvalósulásától, de remélhetjük, hogy belátható időn belül a teljes írott kultúránk átkerül digitális platformra.

Ilyen digitális átállásra már volt példa. A predigitális korban, amikor még nem alakították ki a központi adóbevallás rendszerét, mindenki saját maga készítette el az adóbevallását, noha az adóhivatalban minden adat rendelkezésre állt. Hatalmas előrelépés volt, amikor az adóbevallást átvették, és egyetlen rendszeren belül intézték az erre hivatott szakemberek. A könyvtári rendszer átalakulása hasonló előnyökkel járhat.

A digitális átalakulás belső logikája, valamint az elmúlt évtizedek adatai alapján feltételezhetjük az eddigi trendek folytatódását: arra kell számítanunk, hogy a jövőben tovább csökken az analóg könyvek olvasása iránti „kereslet” a könyvtárakban. Sok könyvtár esetében meg is fog szünni. Nem lehet pontosan megbecsülni, hogy hol és milyen mértékben marad meg az az olvasói tábor, amely azért jár könyvtárba, hogy hagyományos könyveket olvasson, de a digitális olvasás dominanciája erősen valószínüsíthető. A szakkönyvtárak, az egyetemi városok könyvtárai vélhetően kitartanak majd, de a könyvtárak nagy része „,ölöslegessé" válik. Ezt a folyamatot nevezhetjük a könyvtár muzeumizálódásának is. A jövőben csak azok az olvasók járnak hagyományos könyvekért könyvtárba, akiknek a puszta tartalom befogadásán túl másfajta igényeik is lesznek. Mindig fennmarad az érdeklődés a hagyományos könyvek iránt, de az ilyen igények megfogalmazóinak számossága egyre csökken. Feltételezhetjük (remélhetjük), hogy a jövőben sem olvasunk kevesebbet, mint eddig, csak épp az olvasnivaló digitális platformokon kerül elénk. A technológiaváltással az írásos kultúra dokumentumai iránti érdeklődés nem vész el, csak átalakul.

Ha feltételezzük, hogy a könyvek tartalma iránti igény szélesebb körben fennmarad, de elfogadjuk azt a jövőképet is, miszerint a digitális könyvekhez 
való hozzáférés biztosításához elegendő lesz egyetlen digitális platform, akkor felmerül a kérdés, amelyet a jövő döntéshozói egyre gyakrabban fel fognak tenni: szükség van-e könyvtárakra? Az eddig leírtak alapján azt kell válaszolnunk, hogy - a jelenlegi formájukban - nem lesz szükség rájuk. Könyvtárra szükség lesz, könyvtárakra nem. Fel kell tennünk azonban azt a kérdést is, hogy szükség lesz-e a jövőben könyvtárosokra? A válaszunk pedig az kell legyen, hogy: igen, szükség, sőt, még inkább szükség lesz rájuk. Az indokláshoz meg kell vizsgálnunk, hogy mit tud a könyvtáros, milyen munkát végzett a múltban, mit végez a jelenben, és erre a munkára szükség lesz-e a jövőben.

A könyvtáros kompetenciája a könyvekhez (a könyvtárban tárolt információhoz) való hozzáférés elősegítése. Ez a kompetencia kettős. Egyrészt azt jelenti, hogy a könyvtáros az, aki tárolja és leírja a könyvet, vagyis van szaktudása arról, hogy hogyan kell kezelni a könyvet magát. Másrészt elég felkészültnek kell lennie ahhoz, hogy segítsen az olvasónak az ôt érdeklő tartalmak megtalálásában. A digitális könyvek tárolása technikai feladattá válik, így kikerül a könyvtárosi kompetencia köréböl. A metaadatok építésének feladata viszont megmarad, sőt, ennek jelentősége még fel is értékelődik, hiszen a könyvtáros az, aki a múltban építette, és akinek a jövőben is építenie kell azt a szemantikai teret, amely biztosítja a könyvekhez való hozzáférést. A hagyományos világban ezt a szemantikus teret a - katalógusteremben hozzáférhető - katalóguscédulák rendszere, a digitális átállás után a - bárhonnan elérhető - könyvtári adatbázis jelenti. Abból, hogy ezt a szemantikai teret a könyvtáros építette a múltban, és építi a jelenben, még nem következik feltétlenül az, hogy ennek a jövőben is így kell lennie, mert elképzelhető, hogy gépek veszik át ezt a feladatot. Ezt az elméleti lehetőséget nem zárhatjuk ki, bár nem tünik valószínünek a közeli megvalósulása. A könyvtárosoknak adatbázisokat kell építeniük, és az adatbázisok építéséhez szükséges megbízható osztályozási műveletek elvégzését egyelőre csak emberektől remélhetjük. ${ }^{4}$ Minden jel arra mutat, hogy a belátható jövőben is könyvtárosok fogják a könyvek, a könyvkultúra rendszerezését elvégezni. Könyvtárosokra tehát szükség lesz, mert egyrészt ők ismerik a könyvek világát, másrészt ők ismerik a könyvek iránt érdeklődő olvasókat. Ha azt mondjuk, hogy a könyvtáros kompetenciája a könyvekhez való hozzáférés elősegítése, akkor ez egyrészt azt jelenti, hogy a könyvtáros képes eligazodni a könyvekhez vezető utakon a szemantikai térben, másrészt azt is, hogy ezt a tudást képes közvetíteni a hozzá segítségért fordulók, az olvasók felé. Még ha el is fogadjuk azt a víziót, hogy a jövőben a könyvtári rendszerezés feladatát gépek végzik az emberek (könyvtárosok) helyett, akkor is szükség lesz arra, hogy a laikusok segítséget kapjanak az eligazodáshoz, és ezt a tudást még sokáig könyvtárosoktól remélhetjük.

${ }^{4}$ Syi: Olvasni az oszlopok között. $=$ Csomópontok. Szerk. Rab Árpád. Budapest, GondolatInfonia. 2017. 128-153. p. 
Erre a rendszerező, leíró és eligazodási képességre a digitális térben még nagyobb szükség lesz, mivel a digitális kultúra kiépülésével egyre nagyobbá válik az olvasók által elérhető dokumentumgyüjtemény mérete. Douglas Engelbart, a digitális világ egyik korai úttörője (és látnoka) már az 1950-es évek elején felhívta a figyelmet arra, hogy az emberiség számára - a tudástermelés mellett egyre fontosabbá válik a felhalmozott tudás terében való eligazodás képessége. Rheingold így idézi fel Engelbart gondolatait:

„... az emberiség számára többé nem az a legfontosabb feladat, hogy új utakat keressen a további tudásfelhalmozásra. Sokkal inkább azt kell tudni, hol keresse a választ azokra a kérdésekre, melyekre már valahol, valamikor megtalálták és leírták a választ." 5

Engelbart figyelmeztetése nemhogy elavult volna, de egyre érvényesebbé vált és válik a digitális világ kiépülésével. A predigitális kor valamennyi kulturális dokumentumát digitalizáljuk, az új müvek már eleve digitális platformon jönnek létre, megjelennek a felhasználói tartalmak, és amit csak lehet, mérünk, rögzítünk, gyüjtünk és adatbázisokba rendezünk - és ennek köszönhetően ma már szinte naponta annyi információt emelünk be a digitális térbe, mint amennyit korábban évszázadokon, évezredeken át rögzítettünk a hagyományos hordozókra (sziklafalra, papírra, filmszalagra, lemezre stb.). Mi még látjuk a predigitális kor sajátosságait, és ahhoz képest a digitális világ egyik legfontosabb vonásának az adatrobbanás, illetve ezen belül a tartalomrobbanás jelenségét érezzük. ${ }^{6}$ A digitális világba született generációknak már ez a bőség, ez a „termelékenység” lesz a természetes. Az elérhető információ mennyiségében bekövetkezett változás azonban lényegét tekintve nem értékeli át azt a kérdést, hogy ki, milyen szempontok alapján, mit válasszon magának ebből a kínálatból. Az igaz, hogy a digitális platformon hozzáférhető információ mennyisége összemérhetetlen azzal, amelyet az ember befogadni képes, de ez így volt már a predigitális korban is. Ebben a helyzetben (múltban, jelenben, jövőben egyaránt) kánonképző mechanizmusok segíthetik az embert a - mindenképpen szükséges - szürési feladatok ellátásában. Ez igaz, igaz kell legyen a digitális korra is. A digitális átalakulás nem a kánonvesztést, nem a kánonok megszünését hozza el, csak a kánonképző mechanizmusok átalakulását.

Akármilyen kánonképző mechanizmusról is van szó, abban biztosan nagy szerepe kell legyen a kulturális tartalmak leírásának és rendszerezésének. A kanonizálás látványos eleme a rendezés (értékelés, rangsorolás, kiemelés, cenzúrázás),

\footnotetext{
${ }^{5}$ Rheingold, Howard: Tools for Thought. New York, Computer Book Division/Simon \& Schuster. 1985.

${ }^{6}$ Syi: Az adatkor hajnalán. = JEL-KÉP, 2018. 1. sz. 21-34. p.
} 
amelynek mindig van valamilyen elöiró jellege (tiltás, türés, támogatás), de mindez csak akkor lehetséges, ha a korpuszt rendszerezték, és ez utóbbi lényegét tekintve leiró jellegü tevékenységet jelent. Ezt a feladatot - az íráskultúrán belül a könyvtárosok végezték a múltban, és nekik kell elvégezni a belátható jövőben is.

Az emberi tudás felhalmozását az írásbeliség (majd a további médiatechnológiák) elterjedése tette lehetővé. ${ }^{7}$ A predigitális korban az írásbeliség alapegysége a szöveg alapú dokumentum volt, a digitális korban a szöveg mellett megjelent az adatbázis dokumentumtípusa is ${ }^{8}$. Amíg a szövegnek meghatározó minősége az egyediség, addig az adatbázis lényegéhez tartozik az általánosításon és osztályozáson alapuló ismétlődés. A szöveget ezért védi szerzői jog, míg az adatbázis esetében csak a felépítéséhez szükséges munkát lehet a jog által védeni. A könyvek világában a könyvtárosok voltak azok a szakemberek, akik a katalógusok/metaadatbázisok építéséhez szükséges szellemi munkát elvégezték. Akármilyen jövendő világot képzelünk is el, ezt a munkát valakiknek el kell végezni a jövőben is. Eddig a könyvtáros végezte el, és ma még nem tudni, ki más végezhetné el helyette a jövőben.

Összegezve az eddig leírtakat azt mondhatjuk, hogy a digitális világban a hagyományos funkciók nagy részében nem lesz szükség könyvtárakra, mert az olvasók számára kényelmesebb, ha mindent egyetlen (vagy kevés) digitális könyvtárból szereznek be. Ugyanakkor továbbra is szükség lesz a könyvtárosok leíró, osztályozó munkájára, valamint arra, hogy a térben szétszórt és a kultúra iránt érdeklődő emberek eligazodását támogassák. Arra a kérdésre pedig, hogy milyen legyen a jövő digitális könyvtára, nem nagyon lehet mást mondani, mint hogy olyan országos könyvtári rendszert kell kiépíteni, amely az olvasók számára egyetlen szolgáltatásként jelenik meg, miközben a katalogizálási munkát a térben szétszórt, könyvtári szakértelemmel és lokális helyismerettel rendelkező könyvtárosok végzik.

\section{Rezümé}

A digitális technológia elterjedése átalakítja a könyvtári világot is. Ha a könyvek, az írott kultúra dokumentumai mind átkerülnek digitális platformra, az itt tárolt tartalmak hozzáférhetőségét biztosítani lehet akár egyetlen digitális könyvtár fenntartásával is. Úgy tünik, hogy a hagyományos értelemben vett könyvtárakra nem lesz szükség. A digitális kultúra kiépítésében és fenntartásában viszont a korábbiaknál is nagyobb szükség lehet a könyvtárosok szakértelmére, mert a tartalmak leírása, rendszerezése, valamint az érdeklődő olvasók eligazítása a digitális térben könyvtárosi tudást igényel.

\footnotetext{
${ }^{7}$ Ong, Walter J.: Szóbeliség és írásbeliség. Budapest, Gondolat. 2010.

${ }^{8}$ Syi 2017: i. m.
} 


\section{Library, libraries, librarians}

The digital technology is transforming the libraries. If the books and the documents of the written culture are all transferred to a digital platform, the accessibility of the digital content can be ensured even by maintaining a single digital library. It seems that libraries in the traditional may lose their function in the future. However, in building and maintaining the digital culture, the expertise of librarians may be needed even more than before, because the description and cataloguing of content on the one hand and the supporting the readers in the digital space ont he other hand require librarian knowledge.

SZAKADÁT ISTVÁN

BME GTK Szociológia és Kommunikáció Tanszék ORCID: 0000-0002-1960-191X 